\title{
Prevalence of bacterial contaminants in domestic kitchen sinks and laundry machines in houses of Mosul, and the effect of common disinfectants
}

\author{
Shababa A. Bahjet, Sahar S. B. Al-Naqqar \\ Ghada A. M. Al-Taee \\ Department of Biology / college of sciences/ Mosul University \\ Received \\ Accepted \\ 15/10/2006 \\ 09/01/2007
}

\section{المالغص}

مم الحصول على (107 )مسحة منها 54 من مغلبل المالخ و 53 من مكائن غنل الملابس من بعض المنازل في مدينة الموصل منتخبة عثوائيا ـ مم التحري عن وجود الجراثيم الهوائية المحبة لدرجلت الحرارة المعتدلة Pseudomonas و Staphylococci وجراثيم العائلة المعوية .

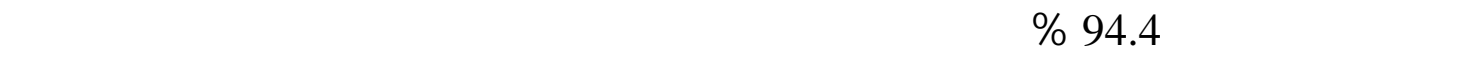

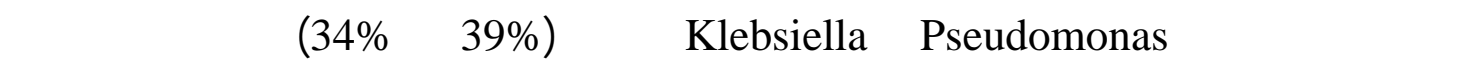

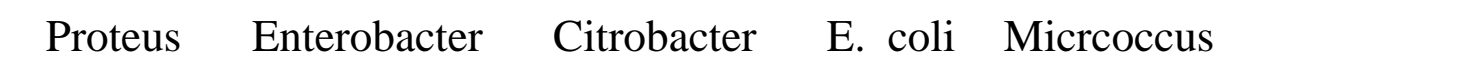
الاغال Salmonella الاغلب بجراثيم Pseudomonas وبنسبة 40\% و

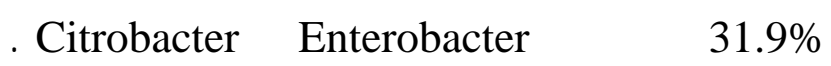

مم لختيارست انواعمن المهرات المتوفرة محلياً وهي Lenol و

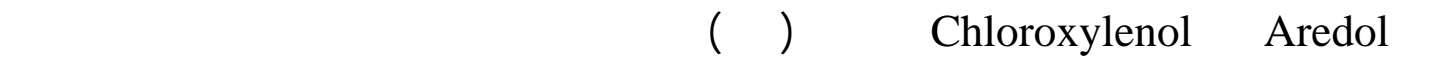

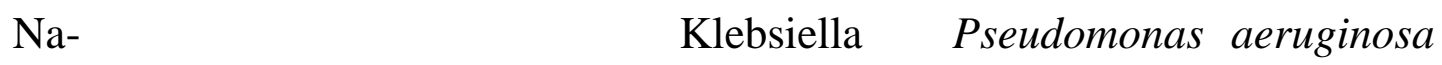
لظهرت فعالية تشبيطية ضـ 2 الع -زلتين hypochlorite, fenetol, chloroxylenol, hexavlon

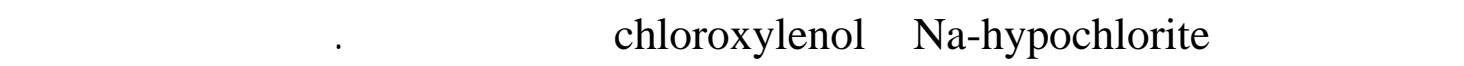
لظهرت فعاليتها بعد الاضلفة مبلثرة.

\section{ABSTRACT}

A total of (107) samples, (54) from kitchen sinks, and (53) from laundry machines were obtained from houses in the city of Mosul . Samples were analyzed for the Presence of Mesophilic aerobic bacteria, Pseudomonas, Staphylococci, and enterobacteriaceae. Results showed that $94.4 \%$ of sink samples were contaminated with one or more microorganisms. Pseudomonas 
and Klebsiella were the two dominant bacteria in addition to coagulase negative micrococcaceae, E. coli, Citrobacter, Enterobacter, Proteus and Salmonella. Also, 69\% of laundry machines were contaminated mostly with pseudomonas, and coagulase negative micrococcaceae, in addition to Enterobacter and Citrobacter . disinfectant were evaluated against Pseudomonas aeroginosa and Klebsiella :Lenol, Fenetol, Hexavlon, Aredol, Chloroxylenol, and Nahypochlorite. The latter was the most effective shortly after its addition .

\section{Introduction}

Previous studies in many countries have drawn attention to the high prevalence of bacterial contamination in the domestic environment .The current attention on bacterial contamination in the kitchen was started in the late 1970s. The first comprehensive study (1) who isolated bacteria from numerous surfaces in homes. The most noted finding was that the kitchen sink was found to harbor large number of bacteria, whereas, toilet areas showed little evidence of contamination with faecal bacteria. A larger investigation was also done by (2) where samples were taken from 201 houses. They found that more than 80 $\%$ of the houses examined contained one or more Enterobacterial spp. Furthermore, they reported in a study in 1984, that cleaning with detergents and hot water produced no reduction in microbial contamination, while using disinfectants under controlled condition produced substantial but brief reduction in microbial contamination.

Kitchen sinks have been found to be rapidly colonized with large number of coliforms within one week of the occupancy of a new house (1) . It was suggested that the coliform are derived from food production brought into the home.

Contamination levels in kitchens of U.K. homes over a 24-hour period was studied by (3). They sampled many sites inside the kitchen like refrigerator handles , kettle handle , work surfaces , ...cutting boards .They found that enterobacterial spp. Contamination level varied during the day , peaking after meal preparation and generally falling overnight .

Studies of the domestic environments by $(1,2,3,4,5$, and 6$)$ indicate that microorganisms including some potentially pathogenic species are commonly found in all areas of the home environment. The results of these studies indicate that wet sites such as kitchen sinks areas ( particularly sink surfaces , draining boards , U-tubes) ,toilet are most commonly associated with heavy contamination and occurrence of potentially harmful species . These results suggest that, in the kitchen, although raw food is probably the main source of contamination, the sink, can also act as semi-permanent source of reservoirs which harbor and encourage the establishment of free living bacterial and fungal population. Another breeding grounds for bacteria are the laundry machines (basin) where there is always accumulated water.$(7,8,9$ ). Although many different detergents wash cycles and commercial and home type machines have been used, the general consensus is that appreciable number of contamination survive and probably recontaminate the next washing load.

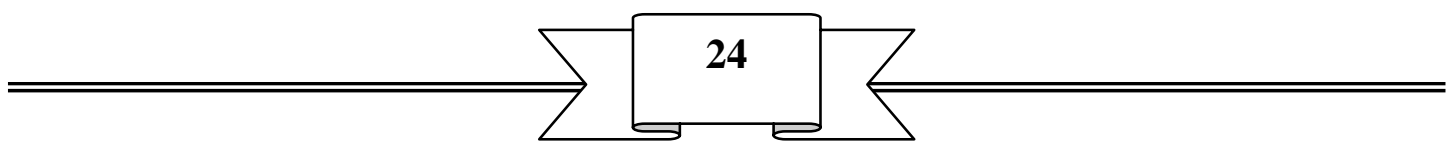


It should be mentioned here, that the kitchen is the most germ-infested spot in the house, according to a university of Arizona study led by Charles Gerba (microbiologist). Bacteria thrive in warm, dark, moist environments. Trapped food particles in the sink, along with moisture, create an ideal environment for bacterial growth. Sink may harbor microscopic germs that can ultimately cause colds, diarrhea, food poisoning and even hepatitis and cancer. Results of these studies, along with the lack of conventional detergents and disinfectants over the past decade or more due to the sanctions imposed on our country has generated increased interest in bacterial contamination in the home in general and kitchens in particular .

\section{Materials and methods}

Early morning swab samples were taken from (54) sink basins and (53) laundry machines in (107) homes in Mosul city. Household samples were randomly selected from $(>20)$ different vicinities. Most of the occupants belonged to college staff members Samples were obtained using sterile swabs moistened with sterile saline solution $(0.85 \%)$ and transferred to the laboratory and processed immediately by inoculating each sample on blood and MacConkey's agar plates. Inverted plates were incubated aerobically at $37^{\circ} \mathrm{c}$ for $24 \mathrm{hr}$. The following criteria were taken into consideration for the identification of bacterial isolates : colony morphology , odor , pigmentation , gram stain , oxidase test , IMViC tests, $\mathrm{H}_{2} \mathrm{~S}$ production (TSI) ,Motility (SIM) and urease test $(10,11,12)$. Two bacterial isolates were then chosen to evaluate six disinfectant products purchased from local markets. The disinfectants used are summarized in table (1).

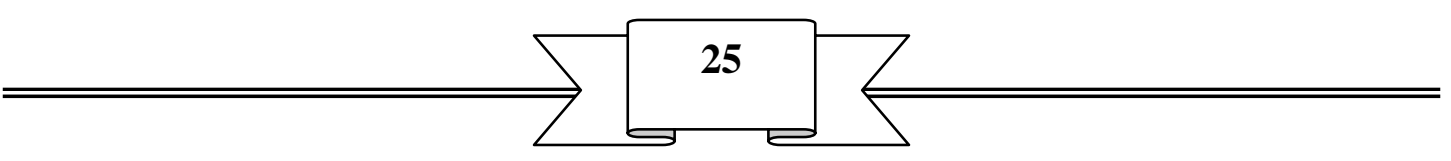




\begin{tabular}{|c|c|c|c|}
\hline & \multicolumn{2}{|c|}{ Prevalence of bacterial contaminants .... } & \\
\hline \multicolumn{4}{|c|}{ Table (1): Names and composition of disinfectants } \\
\hline Name & Company & Chemical composition & concentration \\
\hline$\overline{\text { Lenol }}$ & $\begin{array}{l}\text { Spartan } \\
\text { (Jordan) }\end{array}$ & $\begin{array}{c}\text { Chloroxylenol , pine oil , } \\
\text { caster oil , soap and alcohol }\end{array}$ & Concentrated \\
\hline Fenetol & 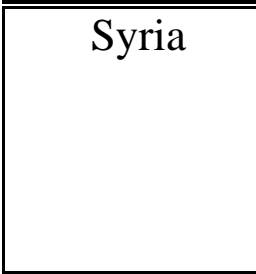 & $\begin{array}{c}\text { 1\% 2-hydroxy } \beta \text {-phenyl ,2- } \\
\text { benzyl 4- } \\
\text { chlorophenyl(product of } \\
\text { german bayer company) } \\
\text { soap and alcohol . }\end{array}$ & Concentrated \\
\hline Aredol & $\begin{array}{l}\text { Al-Amal } \\
\text { (Jordan) }\end{array}$ & $\begin{array}{c}\text { Dichlorometaxylenal (demx) } \\
1-5 \% \text {, edta , isopropyl } \\
\text { alcohol , pine oil castor oil } \\
\text { caustic potash .D.W. }\end{array}$ & Concentrated \\
\hline $\begin{array}{l}\text { Hexavlon } \\
\text { Hex }\end{array}$ & $\begin{array}{l}\text { Al-Arabia } \\
\text { (Syria) }\end{array}$ & \begin{tabular}{|c|} 
Chlorohexidene d-gluconate \\
$0.2 \%$ cetrimide $2 \%$ \\
\end{tabular} & Concentrated \\
\hline $\begin{array}{c}5- \\
\text { chloroxylenol } \\
\text { B.p 5\% }\end{array}$ & SDI (Iraq) & Chlroxylenol B.p 5\% & $2 \%$ \\
\hline 6-Bleach (Fas) & Iraq & Na-hypochlorite & concentrated \\
\hline
\end{tabular}

As a first step evaluation of disinfectant was done sing the disk diffusion method. Bacterial isolate were activated on styptic soy broth and incubated at $37^{\circ} \mathrm{c}$ for $18 \mathrm{hr}$. Nutrient agar plates were seeded with the overnight bacterial culture, left for 5 minutes. Sterile filter papers impregnated with disinfectant (concentrated) were applied on the seeded agar. All plates were incubated at $37^{\circ}$ c for $24 \mathrm{hr}$. The disinfectant that gave inhibition regardless of the size of inhibition zone was chosen to determine the optimum time for killing .

An overnight culture of each bacterial strain was diluted with sterile saline solution to $1 / 10^{5}$ concentration . Equal volumes of bacterial diluted suspension and the disinfectant (Concentration as recommended on the bottle) were mixed in a sterile test tube . At time intervals of 0,15 , and 30 minutes a sample of $0.1 \mathrm{ml}$ was spread on duplicate nutrient agar plates are incubated for $24 \mathrm{hr}$. Control plates with diluted bacteria only ( without disinfectants) were also inoculated in the same manner.

\section{RESULTS AND DISCUSSION}

Within the home, the primary sources by which pathogenic microorganisms are continually and inevitably introduced into this setting are people, food, pets, water, in sects and air. Additionally, sites where stagnant

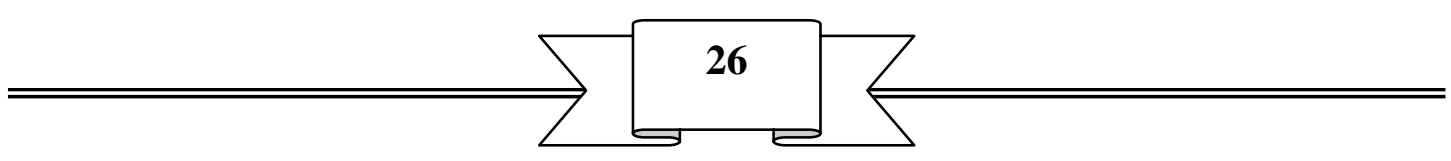


water accumulates, such as in sinks and laundry machines can support growth and become a primary reservoir of known or opportunistic pathogens and bad odors. Once contaminants are introduced and attached to surfaces, particularly in biofilms, it becomes very difficult to remove . They may then grow potentially reaching infectious dose levels and, in the presence of moisture and/or food debris survive to contaminate any thing that comes in contact (hands, utensils, laundry ...). (13) suggested that kitchen surfaces and hands may contaminate each other in a cyclic pattern .The goal of the present study was to determine bacterial contamination in our home setting. Most of the papers published (if not all) investigated the homes of western countries which differs in many ways in respect to cultural , economical , and traditional behavior from the eastern part of the world.

Results of this study are summarized in table (2):

\begin{tabular}{|r||r||r|r|r|r||}
\hline Site & \multicolumn{1}{|c|}{$\begin{array}{c}\text { Total no. of } \\
\text { samples }\end{array}$} & \multicolumn{2}{|c||}{ +ve samples } & \multicolumn{2}{|c||}{-ve samples } \\
\hline \hline & & No. & $\%$ & No. & $\%$ \\
\hline \hline $\begin{array}{c}\text { Kitchen } \\
\text { sink }\end{array}$ & 54 & 51 & 94.4 & 3 & 5.6 \\
\hline \hline $\begin{array}{c}\text { Laundry } \\
\text { machines }\end{array}$ & 53 & 37 & 69.8 & 16 & 30.2 \\
\hline \hline Total & 107 & 88 & & 19 & \\
\hline
\end{tabular}

Pseudomonas spp. had the highest rate as it was found in both sites as a contaminant in 46 out of 107 samples, two isolates of which were Pseudomonas aeruginosa ( obtained form sink samples). The latter was also isolated by Josephson and coworkers in 1997 from 19 out of 100 kitchen sink samples (before the use of disinfectants), and in 14 out of 77 samples (at irregular use of disinfectant ) but no detection of Pseudomonas aeruginosa was found when targeted of disinfectant was used . Enterobacteriaceae isolated from the sink in the present study included Klebsiella , Enterobacters , Citrobacter, Salmonella , Proteus and E.coli .A similar pattern was also reported in the study of $(1,2,4)$. Although these species are not normally pathogenic to the healthy adult, they must be regarded as indicators of poor hygiene. Enterobacteria and pseudomonas may have come into the kitchen on meat and poultry or other food sources.

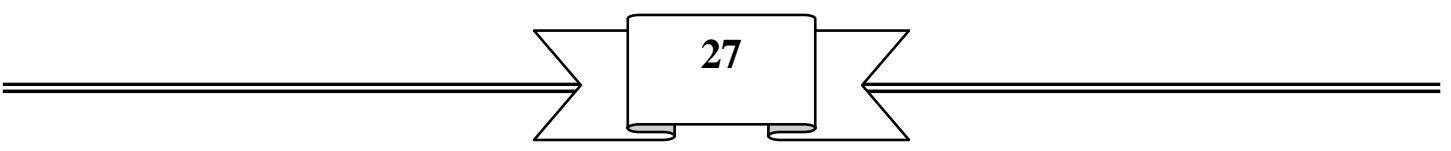




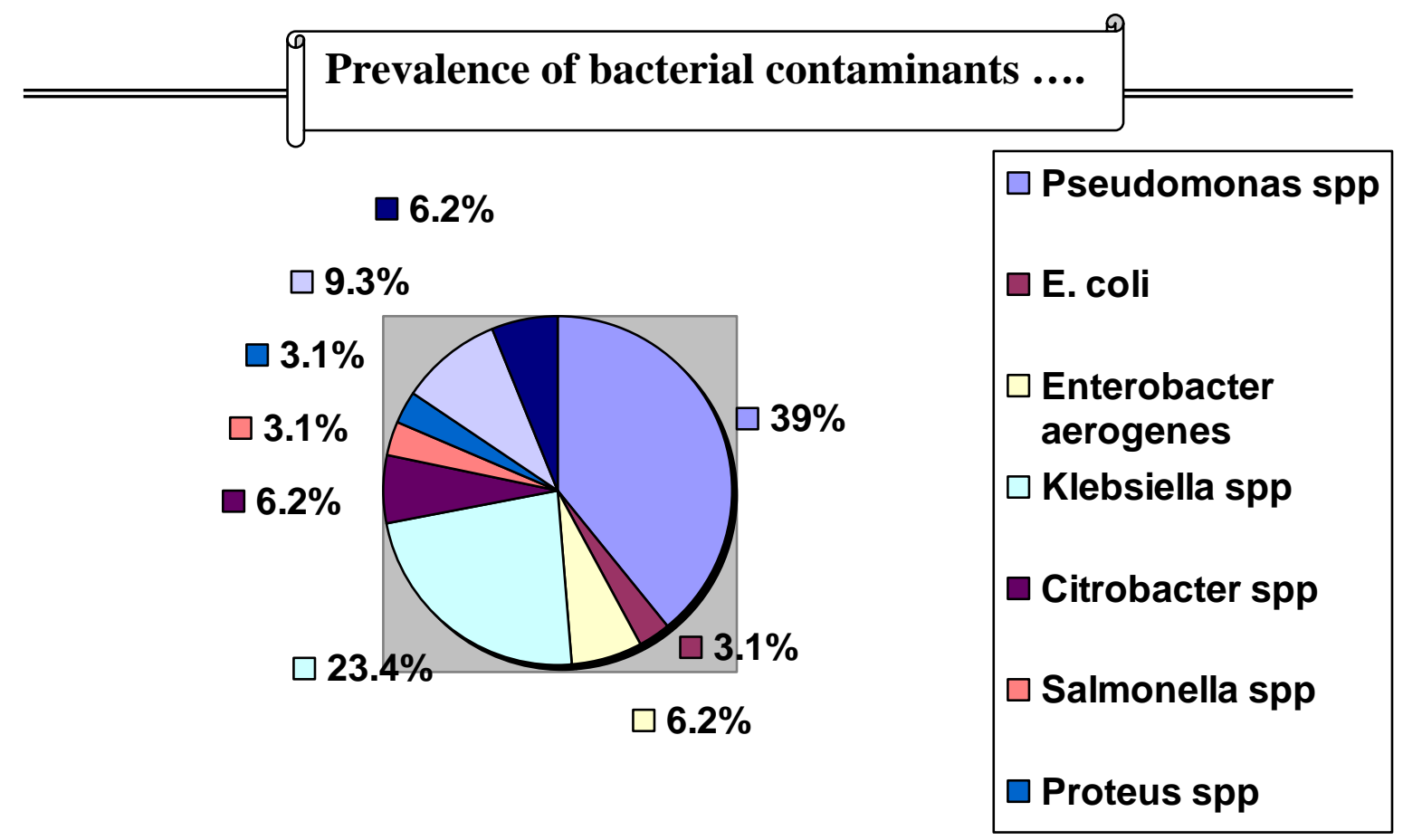

Figure (1):percentage of bacterial species isolated from sink samples

In addition, records showed that a wide ran ge of non food preparation activities took place in the kitchens investigated (3), these include washing hands after gardening , repairing a bicycle , combing children's hair , Feeding pets . Two isolates of proteus were found in houses raising chicken.

Although some of the isolated strains above are relatively non-serious, the consequences of infection can be serious for young children, lderly, neonates, pregnant women, and immune-compromised patients.

As for laundry machines, six bacterial species were isolated from 53 samples. The positive isolates were contaminated with Pseudomonas, Enterobacteria , Klebsiella ,Citrobacter, coagulase negative micrococcacea and Bacillus spp. figure(2) :

The incidence of contamination of laundry machines with gram negative enterobacteria was less than that of the sink . On the contrary, gram positive cocci appeared more in washer samples. This agrees with (8) who showed that gram positive bacteria can be transferred to uncontaminated fabrics during laundering at all wash-water temperatures commonly used in household machines. These results were not unexpected but they emphasize the importance of being aware of the vastly greater resistance of these bacteria compared with gram negative bacteria to the process of wash cycles.

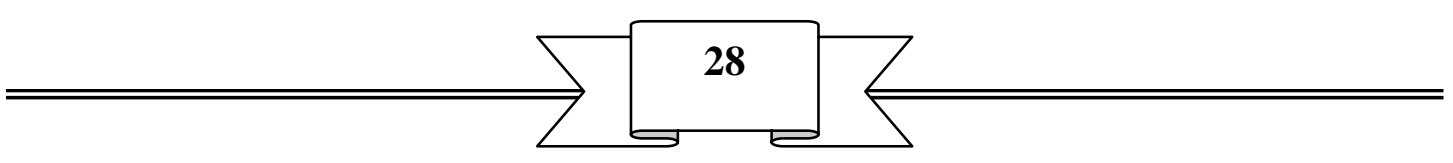



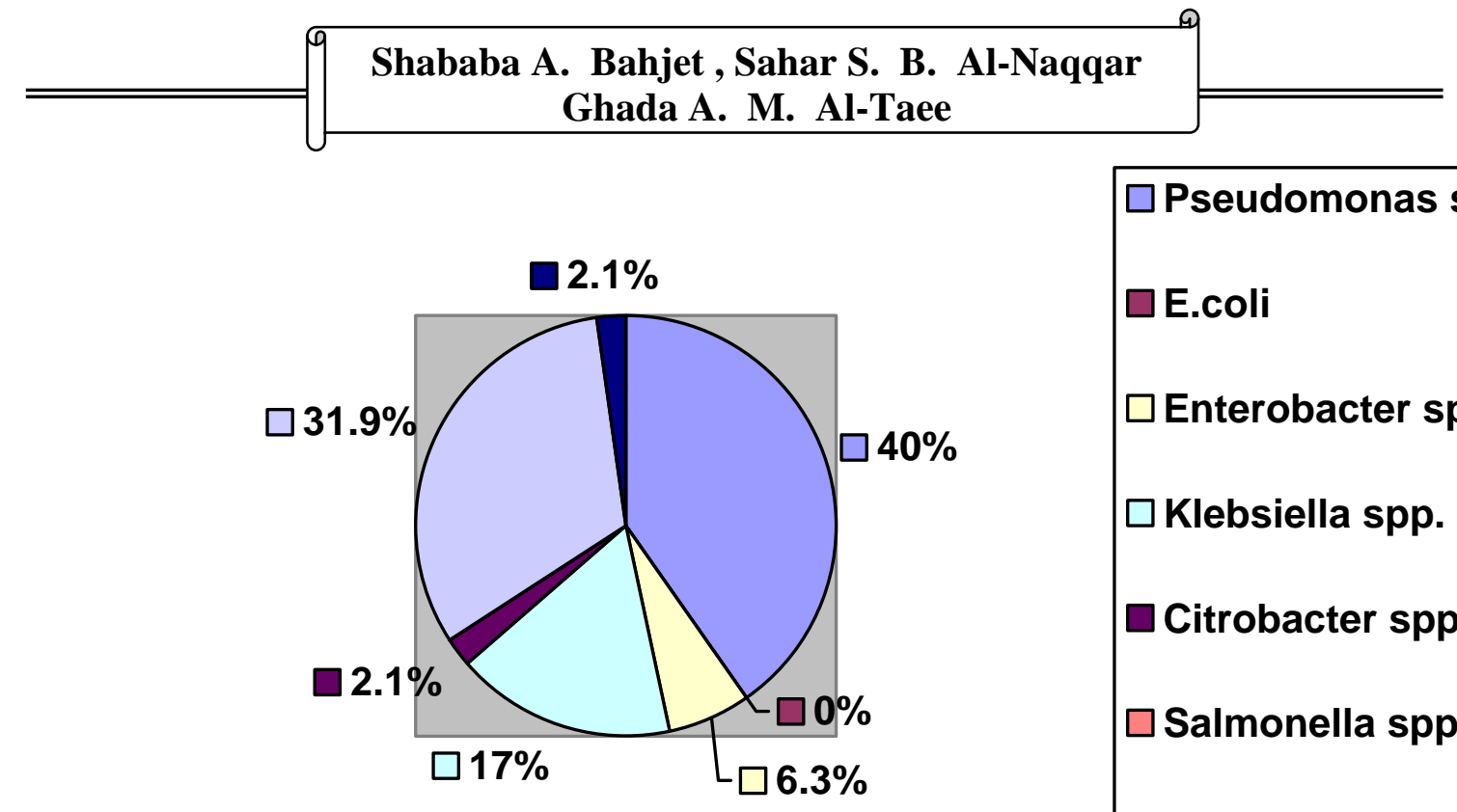

$\square$ Pseudomonas spp.
$\square$ E.coli
$\square$ Enterobacter spp.
$\square$ Klebsiella spp.
$\square$ Citrobacter spp.
$\square$ Salmonella spp.
$\square$ Proteus spp.

Figure (2) Percentage of bacterial species isolated from laundry machines samples.

The ability of some strains of Pseudomonas aeruginosa to produce alginate (a polysaccaride polymer) and Klebsiella to produce a mucoid capsule enables them to adhere to inanimate surfaces as a biofilm. Results also revealed that four out of the six disinfectants showed inhibition of Pseudomonas and Klebsiella as shown in figure (3). Their effect was clear shortly after the application of the disinfectant to the two bacteria types figure (4).

Despite the similarity in types of bacteria obtained in this study with that of others The number of occasions in which faecal bacteria detected in the sink for example, (less than $2 \%$ E. coli) compared to the investigation mentioned earlier (1) was much lower.

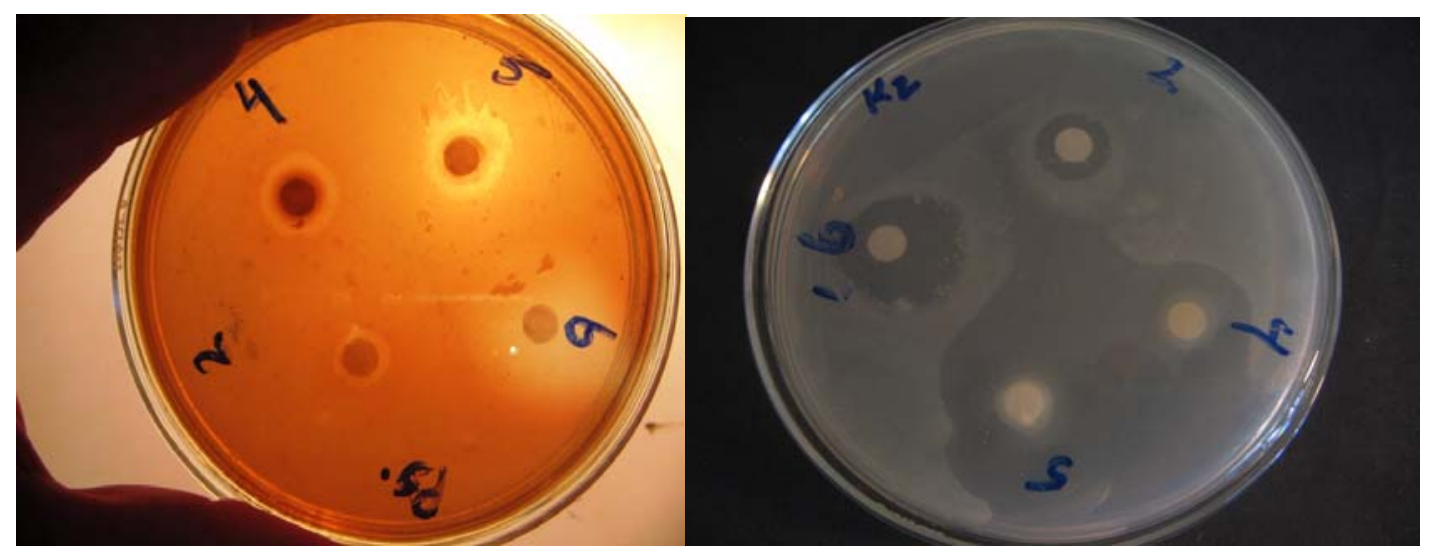

$-\mathrm{A}-$

-B-

Figure (3) Inhibition zones of A- pseudomonas aeruginosa, B- Klebsiella around four disinfectant products: 2 (fenetol), 4 ( hexavlon), 5 (chloroxylenol), 6 ( $\mathrm{Na}$-hypochlorite).

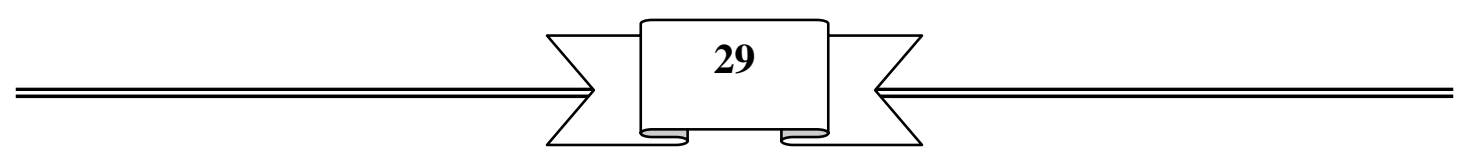



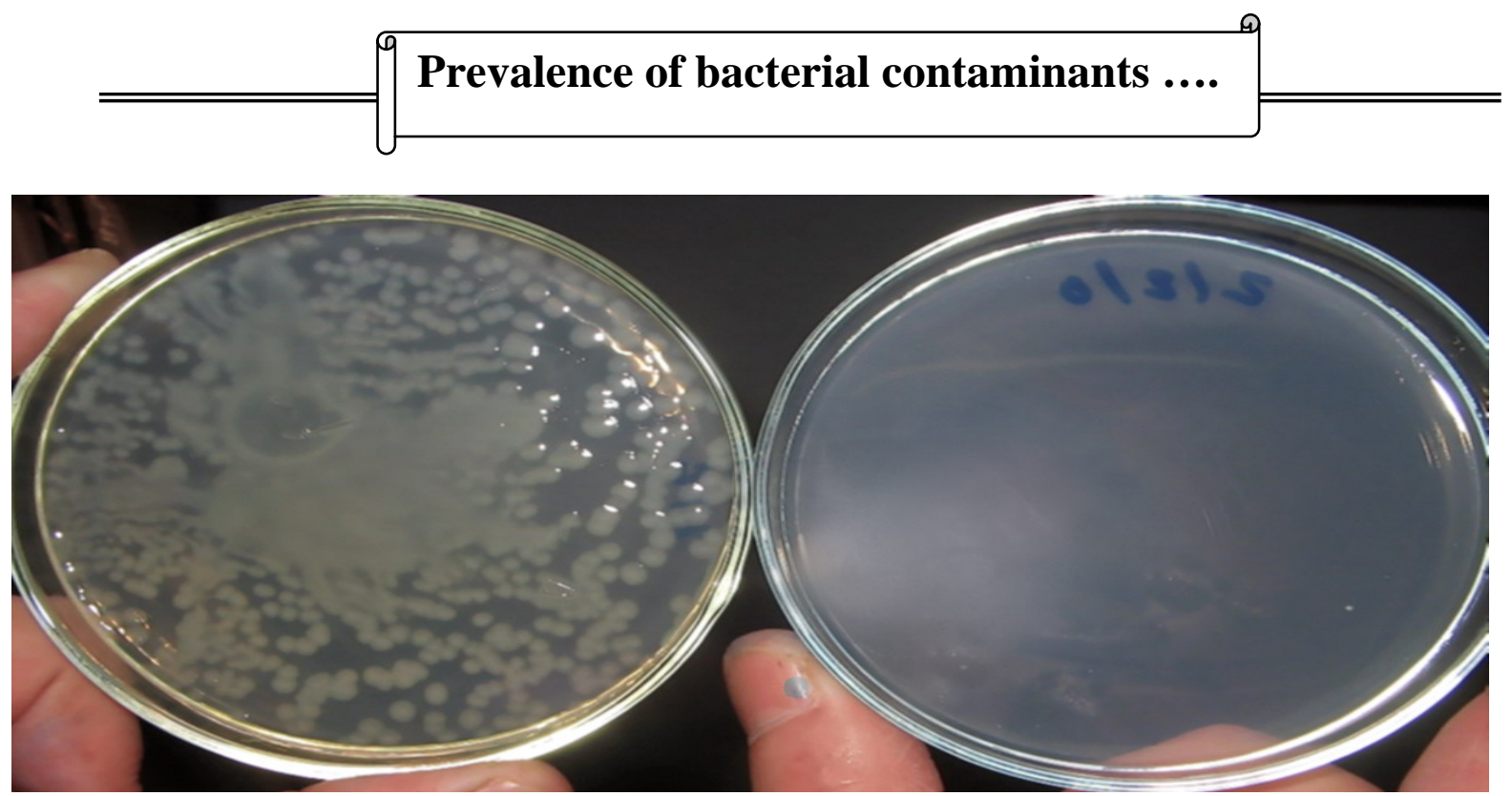

A-

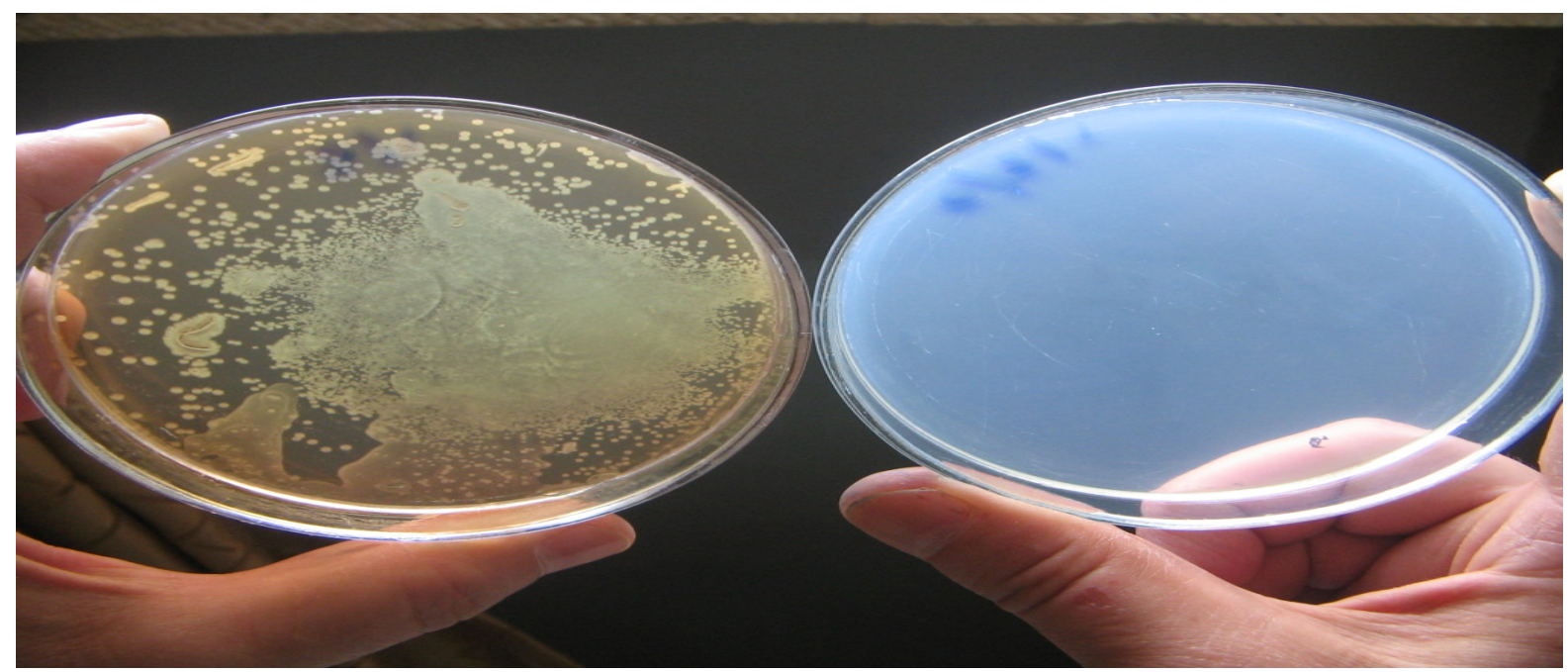

B-

Figure (4)

The effect of Na- hypochlorite(house bleach) on A-Klebsiella ,B- Pseudomonas aeruginosa at zero time as compared with control on the left.

\section{Conclusion}

It must be remembered that the purpose of hygiene procedure must be applied to prevent cross-contamination, and to reduce microorganism to a level that is not harmful to health. It is not intended to achieve sterility and some microbial exposure is expected and is important in maintaining "health" immune system. Despite the similarity in types of bacteria obtained in this study with that of other, the number of occasions in which facal bacteria detected in the sink for example, ( less than 2\% E.coli) compared to the investigations mentioned (1) was much lower . This could implicate better hand washing .The benefit derived from the application of a hygiene procedure depends not only on the effectiveness of the disinfection but also the manner, knowledge and understanding of the person applying them. Further

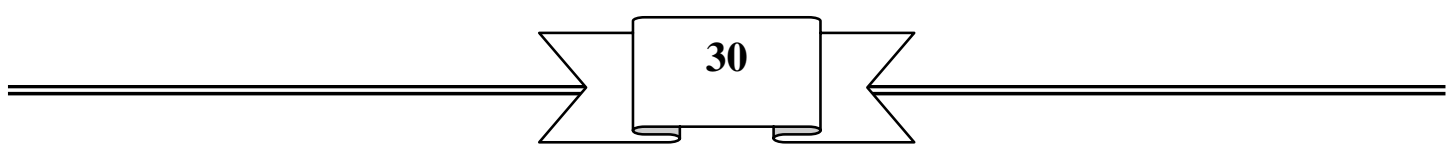


investigations should include a more random selection of homes and occupiers, measurements of counts of bacteria and more sites inside the home to value the degree of hygiene in our homes. It is also recommended to emphasize the role of bleach as a strong disinfectant that gave the biggest inhibition zone, in addition to its lowest price and locally manufactured.

\section{References}

1-Finch J.E , Price , J. and Hawksworth, M. 1978 . A bacteriological survey of the domestic environment . J. Appl. Bacteriology. 45:357-364.

2-Scott, E. , Bloomfield , S.F. , and Barlow , C. G. 1984 . An investigation of microbial contamination in the home. J. Hyg. Cambridge 89:279-293 .

3-Haysaom, L.W. , Sharp, A..K. 2005. Bcterial contamination of domestic kitchens over a 24-hour period. British Food Journal , 107:453-466 .

4-Speirs , J.P. , Anderson, A. , and Anderson JG. 1995. A Study of the Microbiol Content of the domestic kitchen . Internat. J. Environ. Health Research. 5:109-122 .

5-Josephson, K.L., Rubino, J.R. and Pepper I.K. 1997. Characterization and quantification of bacterial pathogens and indicator organisims in household kitchens with and without the use of a disinfectant cleaner. J. Appl.Microbiology 83:737-750 .

6-Rusin, P. Orosz-Coughlin , P. , Gerba, C. 1998 . Reduction of faecal coliform, coliform and heterotrophic plate count bacteria in the household kitchen and bathroom by disinfection with hypochlorite cleaners. J.Appl. Microbiol. 85:819-828.

7-Nicholes, P.S. 1970 . Bacteria in laundered Fabrics . Amer .J. Pub. Health $60: 2175-2180$

8-Wiksell , J.C., Pickatt, M.S. and Hartman, P.A. 1973, Survival of microorganisms in Laundered polyester -cotton sheeting.25(3): 431435.

9-Walter , W.G. , Schillinger , J.E. 1975. Bacterial Survival in Laundered Fabrics. J. Appl. Microbiol 29:368-373 .

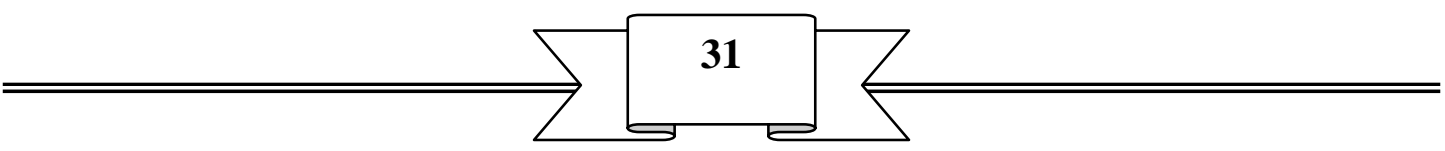


10-Holt, J. G. ., Krieg, N. R ., Sneath, P. H. A. ., Staley, J. T. and Williams, S. T. 1994. Bergey's Manual of determinative Bacteriology. $9^{\text {th }}$. ed. Williams and Wilkans Comp. USA. Baltimore.

11-Koneman, E.W. , Allen S.D. , Janda W. N. , Schreckenberger , P.C. , Winn, W.C. 1997 . Color Atlas and Textbook of diagnostic Microbiology $.5^{\text {th }}$ edition Lippincott -Raven publishers . Philadelphia, U.S.A

12-MacFaddin, J.F. 1985. Biochemical Test for Identification of Medical Bacteria . $2^{\text {nd }}$ Edition .Waverly Press. Incorporation .Baltimore, U.S.A..

13-Van schothorst,M., Huisman, J.and Van Os, M. (1978). Salmonella ondetzobk in huishoudens met Salmonellosis bij zuigelingen . Nederlands Tijscgrift Voor Ganeeskunde. 122:1121-1125.

14-Wilkoff, L.J. , Dixon, G.J. , Westbrook, L. and Happich. W.F. 1971 .Potentially Infetious agents associated with Shear-ling Bed-pads :Effect of Laundering with detergent-Disinfectant Combinations on Staphylococcus aureus and Pseudomonas aeruginosa . 21:647-652 .

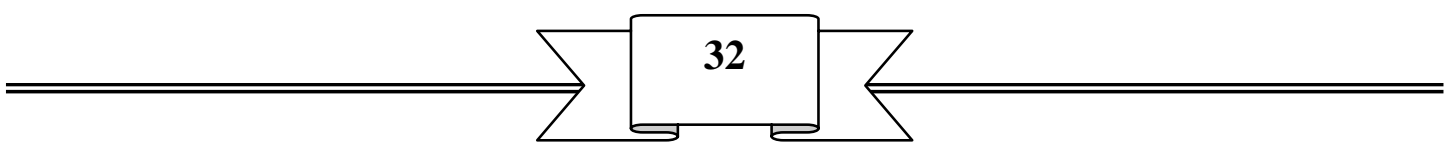

